\title{
At the Turn of the Fourteenth Century: Sigismund of Luxemburg and the Wallachian Princely "Stars" of the Fifteenth Century*
}

\begin{abstract}
Alexandru Simon**
Abstract: In late spring 1398, the noble judges of the Inner Szolnok County rejected John Toth as the legal representative of Stephen I, voivode of Moldavia. Toth (i.e. the Slav/Slovak, chiefly in later centuries) was in fact merely the procurator of Stephen's appointed procurator (representative), a certain John, the son of Costea. Mircea I the Elder, the voivode of Wallachia, was experiencing similar legal problems at the time in the Voivodate of Tran-sylvania. In January 1399, his procurator, Nicholas Dobokai of Ludus,, the son of Ladislas Dobokai (the relative of Mircea's step-uncle, Wladislaw I Vlaicu), had to admit he did not know the exact boundaries of the estate of the Hunyad castle, recently granted by Sigismund of Luxemburg to Mircea. The two documents, almost trivial in essence, point towards two neglected issues: the first Transylvanian estates granted by a king of Hungary to a voivode of Moldavia and to the transalpine origins of the Hunyadi family. Placed in the context of other edited and unedited sources (charters and chronicles), the documents in question provide new perspectives on the beginnings and actions of famed Wallachian personalities of the next century.
\end{abstract}

Keywords: Doboka (Dăbâca), Hunyad, Transylvania, Wallachia, Sigismund Luxemburg, Mircea I of Wallachia, Stephen I of Moldavia, John Hunyadi.

In late spring 1398, the noble judges of the Inner Szolnok County ${ }^{1}$ rejected John Toth as the legal representative of Stephen I, voivode of Moldavia. Toth (i.e.

\footnotetext{
* The paper is the result of a presentation ('Sigismund of Luxemburg and Wallachia in 1387') delivered at the The Court and Chancery of Emperor Sigismund conference, organized by the Masaryk University (Brno) and the Austrian Academy of Sciences, Centre for Medieval Studies (Vienna) in Brno (November 18-21, 2015).

** Research Professor Habil., Romanian Academy, Centre for Transylvanian Studies, Cluj-Napoca; Email: alexandru.simon@acad.ro/ alexandrusimon2003@gmail.com.

${ }^{1}$ For the counties in the area and their peculiarities: András W. Kovács, "The Authorities of Middle Solnoc and Crasna Counties in the Middle Ages", and Géza Hegyi, "The Affiliation of the Sălaj (Szilágy) Region in the Mirror of Social Relations", in Institutional Structures and Elites in the Sălaj Region and in Transylvania in the $14^{\text {th }}-18^{\text {th }}$ Centuries (=Transylvanian Review, XXI, suppl. 2), edited by A. W. Kovács (Cluj-Napoca, 2012), pp. 31-66 (at pp. 43-45), 67-99 (at pp. 77-86).
} 
the Slav/ Slovak) was in fact merely the procurator of Stephen's appointed procurator (representative), a certain John, the son of Costea. ${ }^{2}$ The case apparently went cold.

Nos Leusthasius de Zilagthew, Iohannes, filius Iacobi de Zilkerek, iudices nobilium comitatus de Zonuk interiori, memorie commendamus quod, quia Iacobus dictus Toth coram nobis sic dicebat quod ipse procurator magnifici viri Stephani, vayvode Moldaviensis, esset et in persona ipsius coram nobis setit, cum tamen comes comitatus de Zonuk interiori litteram procuratoriam postulasset et coram nobilibus comprovincie legere fecisset, tamen litera procuratoria non tenebat quod prefatus Iacobus dicturs Toth esset procurator magnifici viri Stephani, vayvode Moldaviensis, sed procurator Iohannis, filii Coztha; ideo, nobiles comprovincie, in sede nostra iudiciaria consedentibus, taliter decreverunt quod procurator procuratorem facere non posset, declarato, tamen, quod prefatum Iacobum dictum Thoth, Iohannes, filius Coztha, officialis viri magnifici Stephani, vayvode Molda-viensis, procuratorem constituisset.// Datum in Dees, feria quarta proxima ante festum Penthecosthes, anno domini MCCC nonagesimo octavo (Dej, May 22, 1398). ${ }^{3}$

Mircea I the Elder, voivode of Wallachia, was experiencing similar legal problems at the time in the Voivodate of Transylvania. ${ }^{4}$ His procurator, Nicholas of Luduş, the son of Ladislas Dobokai, the relative of Mircea's step-uncle, Wladislaw I Vlaicu, ${ }^{5}$ had to admit that he did not know the exact boundaries of the estate of the Hunyad castle, recently granted by Sigismund of Luxemburg to Mircea. Nicholas thus asked for time so that he could grew familiar with the estate. His request was granted. ${ }^{6}$

\footnotetext{
${ }^{2}$ For the document, see also Matei Cazacu, “À propos de Iaţco de Suceava: entre le mythe et la réalité”, in Istoria ca lectură a lumii. Profesorului Alexandru Zub la împlinirea vârstei de 60 de ani, edited by Gabriel Bădărău, Leonid Bociu, Lucian Năstasă (Iaşi, 1994 [1998]), pp. 97-114, at pp. 101-102.

${ }^{3}$ Magyar Országos Levéltár, Budapest, Diplomatikai Levéltár (DL), [no.] 27382; partially edited in Documenta Romaniae Historica (DRH), D. Relaţile între Ţările Române, I. 1222-1456, edited by Ştefan Pascu, Constantin Cihodaru, Konrad G. Gündisch, Damaschin Mioc, Viorica Pervain (Bucharest, 1977), no. 102, pp. 169-170; calendared in Documenta Historiam Valachorum in Hungaria illustrantia, edited by Imre Lukinich, László Gáldi, Antal Fekete Nagy, László Makkai (Budapest, 1940), no. 455, p. 504; and afterwards in Zsigmondkori Oklevéltár, [general-editors Elemér Mályusz, Iván Borsa, Norbert C. Tóth,] I. 1386-1399, edited by E. Mályusz (Budapest, 1951) (ZsO), no. 5330, p. 587.

${ }^{4}$ The legal aspects of such (political) relations have been downplayed rather frequently.

${ }^{5}$ Romanian historiography apparently paid no attention to the identity of Mircea I's procurator ever since the source was officially brought to its attention in the 1950s. For the relation between Wladislaw I and Ladislas Dobokai, to whom he granted estates in the Transylvanian Duchy of Făgăraş: DRH, D, I, no. 60, p. 104 (1372). For the history of the branches of the Dobokai family (of Dăbâca), including that of one ban of Severin, Mikud (in the 1260s-1270s): Marius Diaconescu, Structura nobilimii din Transilvania în epoca angevină (Cluj-Napoca, 2013 [2014]), pp. 185-188.

${ }^{6}$ The source first discussed of Iosif [József] Pataki, "Ceva despre relaţiile Ţăii Româneşti cu Ungaria la sfârşitul veacului al XIV-lea”, Studii şi Materiale de Istorie Medie, II (1957), pp. 421-429, at p. 424.
} 
[...] Nicolaus de Ludas, pro magnifico viro domino Meche, waywoda partis Transalpine, cum procuratoriis litteris eiusdem in nostram [...] castrum Hunyad, simulcum possessionis Saluasara predicta ac aliis possessionibus et portionibus possessionariis, ad idem castrum pertinentibus, de novo [...] per regiam maiestatem [...] collatum existere allegans retulit eo modo, quod ipse de cursibus metarum seu signorum metalium possesionum predictarum et per omnia inscius haberetur [...] (Turda, January 23, 1399). ${ }^{7}$

The two documents, almost trivial in essence, point towards two neglected issues: (1) the first Transylvanian estates granted by a king of Hungary to a voivode of Moldavia ${ }^{8}$ and to (2) the transalpine origins of the Hunyadi family, ${ }^{9}$ although the Hunyad estate (and castle), granted to Mircea, was usually identified with the Bologa castle, near Huedin (Bánffyhunyad in later records), west of the city of Cluj. ${ }^{10}$ Each of the issues seemingly stand at that very basis of the Wallachian policies in the $1400 \mathrm{~s}$.

The Princely Wallachian Roots and Claims of John Hunyadi. A most peculiar copy of the Chronicle of the Counts of Cilly, altered prior to 1504 in the entourage of King Matthias Corvinus' illegitimate son, duke John, claimed that John Hunyadi had in fact been Mircea I's offspring (i.e. son). ${ }^{11}$ John Hunyadi was usually rumoured to have been Sigismund of Luxemburg's natural son (the rumor, launched against John Hunyadi in order to explain his spectacular political rise, was strongly refuted by his son, Matthias;, entourage, though it would have supported the royal candidacy of Matthias' own illegitimate child, John, the only member of the Hunyadi family to officially bear the name Corvinus). ${ }^{12}$ At the time of the royal donation of

\footnotetext{
${ }^{7}$ MOL, DL 28768. Calendared in ZsO, I, no. 5680, p. 627. Passages from the document were edited in DRH, D, I, no. 104, p. 171.

${ }^{8}$ Stephen III was conventionally considered the first Moldavian recipient of such Transylvanian estates, in the last part of Matthias Corvinus' reign (see also M. Diaconescu, "Contribuţii la datarea donaţiei Ciceului şi Cetăţii de Baltă lui Ştefan cel Mare”, Analele Putnei, IX (2013), 1, pp. 91-112).

${ }^{9}$ For an overview of the issue: András Kubinyi, Matthias Rex (Budapest, 2008), pp. 7-12.

${ }^{10}$ For the confusions between Vajdahunyad (Hunedoara) and Bánffy-hunyad (Huedin), designating also the nearby fortress at Bologa (otherwise known as Sebesvár): Pál Engel, Magyarország világi archontológiája 1301-1457, I-II (Budapest, 1996 [CD version 2000]).

${ }^{11}$ Bayerische Staatsbibliothek, Munich (BStB), Abendländische Handschriften, Codices Germanici Monacenses (CGM), [no.] 5350, pp. 89-263: Gräff Zillische Cronnica. Preserved in a copy written after 1624 (because of the reference to the Habsburg embassy to Istanbul, at p. 41), the version was drafted after 1492 (according to the notes on pp. 242, 256), under the patronage of Hartmann Schedel (14401514), the known humanist from Nürnberg; his library also contained the only preserved copy (1502) of the so-called Moldavian-German Chronicle of Stephen III of Moldavia (BStB, Codices Latini Monacenses (CLM), 952. Chronica breviter scripta Stephani dei gratia voivoda terrarum Moldannensium necon Valachyensium). This version that has eluded the learned comparative edition of Franz von Krones (Die Freien von Saneck und ihre Chronik als Grafen von Cilli, I-II (Graz, 1883) can be dated under the circumstances only to the days of John Corvinus ( $\dagger$ October 1504), more precisely after his return to actual Hungarian power (1496-1498). Otherwise, the glorifying "adaptation" of the chronicle would not have aided any member of the Corvinus family.

${ }^{12}$ On John's rise: P. Engel, "Hunyadi pályakezdése", in Nobilimea românească din Transilvania. Az erdélyi román nemesség, edited by M. Diaconescu, Ioan Drăgan (Satu-Mare, 1997), pp. 91-109.
} 
$1398,{ }^{13}$ Mircea of Wallachia already held the Amlaş and Făgăraş duchies in southern Transylvania ${ }^{14}$ and was married to a high-ranking Hungarian lady. ${ }^{15}$

[The sub-chapter] Iohannes Corvini origo, patria et parentes [began with] Merckh [name placed above the actual text as sort of title] dessen Herkommens Corvinus gewesen <ist>. Corvinus war von sainem Vathern ein Wallach, von der Muther ein Kriegh [Greek] und hat sein Geschlecht durch mancherley ritterliche Thathen zu grossen Ehren bracht, und ist für sich selbst auch nit von schlechten Leithen gebohren gewest. [...] [The classical presentation of the Roman roots of the Wallachian followed. Then, starting at John's birth in Corvino (Cuvin/ Keve on the Danube), like in Antonio Bonfini's Decades, the story returned - by means of the Wallachian-Serbian-Hungarian melting-pot on the Danube ${ }^{16}$ - to the origins of John's mother.] [...]Die Mutter ist von Reiss, alter Geschlechte [i.e. John's mother was from Rascia/ Serbia. $]^{17}[$...] [The presentation in the altered chroncile concluded with John Hunyadi's "apotheosis".] [...] Was Corvinus für ein Mann gewessen? Er war ein solcher Mann in welichem erschiene die römische Dapfferkhait, Waisheit und treue Mannheit. [...]. ${ }^{18}$

At about the same time (c. 1399), the influential monk, Nicodimus of Tismana, of princely Serbian descent, closely connected to Sigismund of Luxemburg, ${ }^{19}$ left Wallachia. He settled in the Hunyad County (for some sixe years),

13 The above-quoted charter prevents us from endorsing a much earlier dating. The donation was probably a result of the failed crusade of Nicopolis (1396). Hence, the donation took place the earliest in 1397. The same largely applies in the case of Stephen I.

${ }^{14}$ Despite the obviously nationalist title, see also Ilie Minea, Din trecutul stăpânirii româneşti asupra Ardealului. Pierderea Amlaşului şi Făgăraşului (offprint Convorbiri Literare, XLVIII) (Bucharest, 1914).

15 The Hungarian charters recorded her only as the wife of Mircea. The same later applied for Vlad III Dracula's first wife, closely related to Matthias. The Wallachian sources named her soley the mother of Michael, Mircea's son and heir. Because of her estates in Hungary proper (near Balaton), she was considered a member of the Bánffy family of the Tomai kindred (see also Ioan-Aurel Pop, "Stăpânirile lui Mircea în Transilvania", Revista de Istorie, XXXIX (1986), 7, pp. 685-695, at p. 693).

${ }^{16}$ See in these matters also Péter Kulcsár, "Antonio Bonfini és mủve", in A. Bonfini, A mayar történelem tizedei, translated by P. Kulcsár (Budapest, 1995), pp. 915-922. The manuscript of Bonfini († c. 1502) was well in political circulation by the time of the Congress of Vienna (1515).

${ }^{17}$ For further information on these questions: Al. Simon, "La parentèle ottomane du roi Mathias Corvin", in Matthias Corvinus und seine Zeit: Europa am Übergang vom Mittelalter zur Neuzeit zwischen Wien und Konstantinopel (=Denkschriften der Österreichischen Akademie der Wissenschaften, CDX), edited by Christian Gastgeber, Ekaterini Mitsiou, I.-A. Pop, Mihailo Popović, Johannes Preiser Kapeller, Al. Simon (Vienna, 2011), pp. 25-33. Because of the various SerbianByzantine matrimonial ties, the statement above did not actually contradict the previously asserted Greek origins of John's mother. In effect, in the end, the story implied a Hunyadi (Corvinus) genetic synthesis between the Romans (through the Wallachian father of John) and the Greeks (through his Serbian mother).

${ }^{18}$ BStB, CGM 5350, pp. 174, 176-177. An edition of this version could prove most useful.

${ }^{19}$ See also the data in Đurađ Sp. Radojičić, "Bulgaroalbanitoblahos et Serboalbanitobulgaroblahos: deux caractéristiques ethniques du Sud-Est Européen du XIV et $\mathrm{XV}^{\mathrm{e}}$ siècle. Nicodème de Tismana et Grégoire Camblak", Romanoslavica, XIII (1966), pp. 77-79. 
most likely at the Prislop Monastery. ${ }^{20}$ In stories on Nicodimus' miracles, Matthias occasionally took Sigismund's place as the Hungarian king impressed by Nicodimus' Orthodox virtue. ${ }^{21}$

Rather unsurprisingly, while on the eventually disastrous road to Varna (1444), John Hunyadi confirmed Sigismund's privileges ${ }^{22}$ for the monastic foundations of Nicodimus in Western Wallachia (i.e. Oltenia): Tismana and Vodiţa. ${ }^{23}$ In 1473, when Usun Hassan's victory over Mehmed II in Asian Minor seemed sealed (the opposite occured), Matthias granted special freedoms to the Monastery of Cozia (similarly in Oltenia), the necropolis of Mircea I of Wallachia. ${ }^{24}$ Both father and son, John (who had been promised the crown of Bulgaria in mid-1444), and Matthias, focused on the Monasteries of Tismana, Vodiţa and Cozia, on the eve of major antiOttoman offensive. These onslaughts were - supposed - to alter the status of Wallachia, and consequently that of its western parts (northern Oltenia, i.e., the Gorj region, if not entire Oltenia, named the Land of Severin, had been united with the Land of Hațeg until the 1270s, when the latter was incorporated into the Hunedoara County). ${ }^{25}$

In 1409 , roughly a decade after the royal donation of Hunyad to Mircea, and also after Nicodimus' return to Wallachia (by 1406), ${ }^{26}$ Sigismund officially granted

${ }^{20}$ See I.-A. Pop, Al. Simon, "Misiunile Sfântului Nicodim în contextul politicilor bisericeşti ale Veneţiei şi Ungariei", Mitropolia Olteniei, LVIII (2006), 9-12, pp. 234-252. We use the Hungarian denomination of the county instead of the Romanian one (Hunedoara) because of issue of the identities of the Hunyad castles of 1399 and 1409. The name <Bánffy->Hunyad was later applied to the Huedin borough in the vicinity of the Bologa fortress (in Cluj County). The name Hunyad stood for both the fortress and the county (Hunedoara), where the transalpine members of the Hunyadi family settled. Nicodimus' temporary residence was in nearby Prislop (at least at the end of stay in Transylvania). There, in 6912 (1404/1405), he was in his sixth year of refuge, according to a manuscript note. Within probably a year (certainly by 1406), Nicodimus returned to Wallachia, prior to the Severin meeting and reconciliation between Sigismund and Mircea (November 1406).

${ }^{21}$ For these hagiographic relations: Virgil Ciocîltan, "Întelesul politic al minunii Sfântului Nicodim de la Tismana”, Studii şi Materiale de Istorie Medie, XXII (2004), pp. 153-168, with further references.

${ }^{22}$ DRH, D, I, no. 276, pp. 384-387. The charter was issued at the start of the campaign of Varna (that ended in disaster on November 10), in Orşova (on the Danube), on September 20, 1444.

${ }^{23}$ DRH, D, I, no. 125 , pp. 204-205; nos. 128-129, pp. 210-212; no. 169, pp. 266-268. All royal (Hungarian) privileges (1419-1428) were issued after Mircea I's death (1418). Only Drachendespot Stephen Lazarević, Nicodimus' relative, granted a (Serbian) privilege during Mircea's rule (1406).

${ }^{24}$ DRH, B. Tara Românească, I. 1250-1500, edited by P.P. Panaitescu, Damaschin Mioc (Bucharest, 1966), no. 144, pp. 240-241. The royal deed was issued on June 29, 1473. At that time, Mehmed II was fighting Usun Hassan in Asia Minor. The sultan eventually won in early August. Supported by Matthias Corvinus, Stephen III then attacked pro-Ottoman Wallachia in November 1473.

${ }^{25}$ King Louis I of Anjou "returned" to the lords of (unified) Wallachia only (the Duchies of) Amlaş and Făgăraş. The "return" of Haţeg would have signified the complete loss of direct royal control over the Southern Carpathians, except the Saxon centers of Sibiu, north-west of Amlaş, and Braşov, east of Făgăraş (with emphasis on the 1360s, see I.-A. Pop, From the Hands of the Schismatic Wallachians: The Romanians and Power in the Medieval Kingdom of Hungary $\left(13^{\text {th }}-14^{\text {th }}\right.$ Centuries) (New YorkOxford-Frankfurt-am-Main-Basel-Vienna, 2013), pp. 414-434, 457-478)..

${ }^{26}$ In addition to the abovementioned "coincidences", the events must be viewed in connection because of the debates on the actual date when the Hunyad estate was donated to Voicu. The royal deed of 1409 
the Hunyad castle, in south-western Transylvania (in the Land of Haţeg), ${ }^{27}$ to Voicu and his kindred, including his son, John, the future John Hunyadi. ${ }^{28}$ Jancho (Johnnie in Serbian) in Balkan, Wallachian, as well as in Italian milieus, ${ }^{29}$ John Hunyadi, already regent (governour) of Hungary at that time, claimed - for a short while - the throne of Wallachia for himself (in early December 1447), after executing the illegitimate son of Mircea, Vlad II Dracul, father to the infamous Vlad III the Impaler (Dracula).$^{30}$ Albeit rather fictional, the idea of Matthias Corvinus' retaking parental Wallachia - as king of Hungary (moreover) - made quite an "international" career until the end of the fifteenth century, reaching even Burgundy and also France in Western Europe. ${ }^{31}$

was also viewed as a reconfirmation of an earlier royal grant (for an overview: Radu Lupescu, "Matthias Hunyadi: from the Family Origins to the Threshold of Power", in Matthias Corvinus, the King: Tradition and Renewal in the Hungarian Royal Court 1458-1490, edited by Péter Farbaky, Enikö Spekner, Katalin Szende, András Végh (Budapest, 2008), pp. 35-49, at p. 39).

${ }^{27}$ Church history might be useful for the understanding of these issues (usually dealt with separately): Haţeg vs Amlaş and Făgăraş. In the 1390s, the Greek rite authority over Transylvania (the voivodate and its Hungarian "appendixes") was divided - north vs south - with the approval of the royal crown and the benediction of the Ecumenical Patriarchate of Constantinople (for the context: SS. Papacostea, "Byzance et la création de la Métropole de Moldavie", Études Byzantines et Post-Byzantines, II (1991), pp. 133-150). The northern parts, down to the Someş rivers, were entrusted to the Peri stavrophighia (in the Maramureş County), founded by the Dragoş family. The southern parts reverted to the Metropolitanate of Wallachia (Ungrovlachia in official records). The only exception was the Land of Haţeg (i.e. the Hunedoara County). Certainly between 1404 and 1407 (precisely on the eve of the first official record on the Hunyadi family in the region, in 1409 and during Nicodimus' stay at Prislop, between 1398/1399 and 1405/1406) the land was under the ecclesiastical control of the Metropolitanate of Severin (Vladimir Agrigoroaiei, "An Interpretatio Wallahica of Serbian Cultural Patterns: The Cases of Ribiţa, Streisângiorgiu and Crişcior (but also Râmeț)", in Transylvania in the Thirteenth to Sixteenth Centuries: Aspects of the Formation and Consolidation of Regional Identity (=Annales Universitatis Apulensis. Series Historica, XVI, 2), edited by Cosmin Popa-Gorjanu (Alba Iulia, 2012), pp. 105-136, at pp. 110-112). The natural connection between the Severin (the Banate of) and Haţeg influenced also the beginnings of John Hunyadi's career. He made his military and political debut on the Danube, under Pippo Spano and Stephen Lazarević (hence also the Cuvin/ Keve legend).

${ }^{28}$ For a summary of his rise (based on the main known sources and literature): Kubinyi, Matthias Rex, pp. 7-13; Lupescu, "Matthias Hunyadi”, pp. 38-44.

${ }^{29}$ For more information on these matters: I.-A. Pop, "The Names in the Family of King Matthias: From Old Sources to Contemporary Historiography", in Matthias Rex 1458-1490. Hungary at the Dawn of the Renaissance (=Ethnographica et folkloristica Carpathica, XVII), edited by Elek Bartha, Róbert Keményfi, Zsófia Vincze Kata (Debrecen, 2012), pp. 11-40.

${ }^{30}$ MOL, DL 29793 (4 ${ }^{\text {th }}$ of December 1447; last edited in DRH, D, I, no. 286, pp. 394-396). Johannes de Hunyad, regni Hungariae gubernator ac, Dei gracia, parcium Transalpinarum wayuoda, issued the charter in civitate nostra Tergouisthya [Târgovişte, the capital of Wallachia]. For the HungarianWallachian-Ottoman context: Francisc Pall, "Intervenţia lui Iancu de Hunedoara în Ţara Românească şi Moldova în anii 1447-1448”, Studii. Revistă de Istorie, XVI (1963), 5, pp. 1049-1072.

${ }^{31}$ E.g. Philippe de Commynes, Mémoires, edited by Joseph Calmette, I. 1464-1473 (Paris, 1924), p. 339; II. 1474-1483 (Paris, 1925), pp. 335-338; III. 1484-1498 (Paris 1925), p. 169. Much of the information was probably circulated in the late 1480s, when King Matthias attempted to secure the custody of Sultan Bayezid II's brother, Djem, who was held by the Knights Hospitaller in their centres in the French realm (Al. Simon, "Lumea lui Djem. Buda, Suceava şi Istanbul în anii 1480", Anuarul Institutului de Istorie George Bariţiu, XLVIII (2005), pp. 11-43). 
Moldavia and the Heirs of Dragoş (of Maramureş) and Voicu (of Hunyad). The Hunyadi princely Wallachian claims seemingly exceeded medieval relations and facts. ${ }^{32}$ Yet they appear to have been well-rooted in Sigismund's deeds and charters from the end of the $14^{\text {th }}(1398-1399)^{33}$ and the beginning of the $15^{\text {th }}$ century (1405-1409) ${ }^{34}$. Almost naturally, the Wallachian deeds of Sigismund were chronologically separated by the Hungarian pro-Angevine rebellion that nearly brought his reign to an end. ${ }^{35}$ Almost paradoxically, the latter events return our attention to Stephen I.

${ }^{32}$ It would be the safest assumption under the present circumstances (see also Péter E. Kovács, "A Hunyadi család", in Mátyás király. Emlékkönyv Mátyás király halálának 500. evfordulójára, edited by Gyula Rázsó, László V. Molnár (Budapest, 1990), pp. 29-51). The extant medieval information also enables "bolder" perspectives. At any rate, Voicu's rank of court knight clearly indicates that he belonged to the "better families" (Kubinyi, Matthias Rex, pp. 8-9). Drag's son, Alexander (1419), enjoyed the same status, even after his father's downfall (ZsO, VII. 1419-1420 (Budapest, 2001), no. 1174, p. 287), and so did, Vlad II Dracul, the illegitimate son of Mircea I, and later also member of the Order of the Dragon (see also DRH, D, I, no. 172, pp. 273-274; no. 179, pp. 279-280).

${ }^{33}$ In effect, the charters on Stephen I's and Mircea I's Transylvanian (feudal) concerns (May 1398 and January 1399) point - because of their necessary legal background - towards the Diet of Timişoara (E. Mályusz, Kaiser Sigismund in Ungarn (1387-1437) (Budapest, 1990), pp. 46-48, 136-166). Unfortunately, unlike in the case of the Hungarian Diet of April 1467 (that approved direct royal control over Amlaş, Făgăraş and Rodna, in view of their granting to the voivodes of Wallachia and Moldavia, on the eve of another planned anti-Ottoman offensive) no records from the file of Diet of SeptemberOctober 1397, related to the lords of Wallachia and Moldavia, have been identified so far. In relation to the 1390 s and to the early 1400 s, the matter is of particular importance because - on ecclesiastical soil (where the Church largely followed the lines laid down by the secular administration, either through stately units or through large estates, such as those of the Dragoş) - Haţeg belonged to a different "entity". Though nominally a part of the Voivodate of Transyl-vania, the land (included in the Hunedoara County) belonged to structure around Severin, basically an extended version of the socalled Land of Severin (that - under the last Arpadians - had encompassed Western Wallachia/ Oltenia). In effect, Severin (proper), Oltenia and Haţeg formed - from a royal perspective - one entity. At least two thirds (Severin and Oltenia) were held by Mircea, ban of Severin. The acceptance of the "Olt union" between Oltenia and Muntenia (central Wallachia) was been one the main issues in the relation between the Angevine kings and the first voivodes of (Transalpine) Wallachia (Ş. Papacostea, "Prima unire românească. Voievodatul de Argeş şi Ţara Severin", Studii şi Materiale de Istorie Medie, XXVIII (2010), pp. 9-24).

${ }^{34}$ In this chronological framework, we must single out the meeting between Sigismund and Mircea at Severin (a Hungarian-Wallachian condominium) in November 1406, most likely brokered by Nicodimus (P.P. Panaitescu, Mircea cel Bătrân, edited by Gheorghe Lazăr (Bucharest, 2000²), pp. 368369). In that context, Nicodimus' monastic foundations received grants from both Mircea and despot Stephen Lazarevic (reconciled on this occasion with the lord of Wallachia), one of the "founding members" (as a Greek rite Christian) of the Order of the Dragon in 1408 (M. Popović, "The Order of the Dragon and the Serbian Despot Stefan Lazarević", in Emperor Sigismund and the Orthodox World (=Denkschriften der Österreichischen Akademie der Wissenschaften, CDIX), edited by E. Mitsiou, M. Popović, J. Preiser-Kapeller, Al. Simon (Vienna, 2010), pp. 103-106).

${ }^{35}$ For an outline of the events between 1398 and 1403: Mályusz, Kaiser Sigismund, pp. 59-68. The Wallachian involvement in the crisis still has to be researched. In comparison, we re-draw attention to the role of Dan I (c. 1382-1386), Mircea's step-brother and predecessor, in the previous Hungarian civil war, more precisely to a passage, ad annum 1386, from a passage in Hector von Müllich's chronicle 
The archenemies of Stephen I's House (of Bogdan), the Drágffy family (i.e. the House of Dragoş), ${ }^{36}$ previously Sigismund's loyal supporters, were among the king's main opponents during that rebellion. ${ }^{37}$ Based in the County of Maramureş, north of Transylvania, the Drágffys, who had previously acted as mediators between the king and the Wallachians in the Land of Haţeg, ${ }^{38}$ also held important estates in the Inner Szolnok County. ${ }^{39}$ These estates were - now - bordered by Stephen's lands. ${ }^{40}$

(c. 1420-c. 1490): [...] Am Sant Jacobs Tag [July 25 <1386>] kam der Wasserwaider von Ungern [Dan I of Wallachia] and den Groß Grafen von Ungern [count-palatine Nicholas (I) Garai] und schlug den im Veld zu Tod und enthauptet ainen Ritter, der den Künig Karl von Pülen [Charles of Anjou/ Durazzo] ermodet hett, und pracht die Künigin von Ungern [Elisabeth, Louis I's widow, accompanied by her daugther, Maria, Sigismund's wife] zu Väncknus, die das Mord gestiftet hett, da ward Sigismund [of Luxemburg] Künig zu Hungern, der hernach Kaiser ward [...] (Die Chronik des Hector <von>Müllich, 1348-1487, in Die Chroniken der schwäbischen Städte, III. Augsburg (=Die Chroniken der deutschen Städte vom 14. bis ins 16. Jahrhundert, XXII), edited by Franz Roth (Leipzig, 1892),pp. 1-274, at p. 29; cf. Alexandru Ciocîltan, "Din biografia cavalerului Friedrich von Kreuzpeck", Revista Istorică, NS, XXI (2010), 5-6, pp. 537-550, at p. 545, note 44).

36 M. Diaconescu, "Dragoş descălecătorul Moldovei: între legendă şi realitate", in Nobilimea românească din Transilvania, pp. 77-90. Dragoş was a "royal creation". He made his fortune serving Louis I.

${ }^{37}$ For an "eastern perspective": K.G. Gündisch, "Siebenbürgen und der Aufruhr von 1403 gegen Sigismund von Luxemburg", Revue Roumaine d'Histoire, XVI (1976), 3, pp. 399-420.

${ }^{38}$ For a discussion of the sources: Radu Popa, La începuturile Evului Mediu românesc: Țara Haţegului in secolul al XIV-lea (Bucharest, 1988), pp. 291-293. Without entering any "pan-Wallachian" rhetoric, it is obvious that the Dragoş kindred (who - furthermore - had preserved their Greek rite even under Louis I) had at that time the dominant position among the Wallachians in the Hungarian realm, with a - seemingly direct - impact over both "Wallachian borders" of the kingdom (see also M. Diaconescu, Erika Kató, "Incursiunea moldovenilor în Maramureş în 1395. Noi aspecte ale relaţiilor moldo-polone', Anuarul Institutului de Istorie A.D. Xenopol, XXXII (1995), pp. 147-155). In order to have an insight into the complexity of these border relations, we must note that in early 1395 Sigismund attacked Moldavia via its southern pro-Hungarian Lower Country, and Stephen I responded with a raid in northern Maramureş, by then the "fief" of the Dragoş family. The same pattern ("plus" a Moldavian attack on the Szeklerland in eastern Transylvania) applied for the confrontations of 1467-1469 between Matthias and Stephen III (Ş. Papacostea, "Un épisode de la rivalité polono-hongroise au XVe siècle: la campagne de Mathias Corvin en Moldavie (1467) à la lumière d'une source inédite", Revue Roumaine d'Histoire (Bucarest), VIII (1969), 6, pp. 967-979). In reference to the events seven decades earlier, we also recall the royal (Arpadian) administrative "foundation" of future Moldavia, the Borkoth County (north of the Lower Country of Moldavia), designation featured in a neglected papal charter from 1327 (Al. Simon, "Principele Dominic, secuii şi Ţara de Jos a Moldovei", Anuarul Institutului de Istorie A.D.Xenopol, LI (2014), suppl., pp. 59-76).

${ }^{39}$ Lajos Thálloczy, A Kamara Haszna (lucrum camerae) története kapcsolatban a magyar adó- és pénzügy fejlödésével (Budapest, 1879), Appendix, no. 37, pp. 180-185. The data from 1427-1428 (more than two decades after the downfall of the family) reveals the significant extent of the estates of Drágffy in the Inner Szolnok County, as well as a multitude of voivodes in the region, altogether a rather problematic local feudal system.

40 The involvement of the judges of the county and the presence of the procurator(s) of Stephen I can only be associated with a feudal matter within the boundaries of the In-ner Szolnok County. In the absence of any other evidence, we must presume that the issue of the estate(s) did not predate the reign of Sigismund (and, given the extant sources, the rule of Roman I, the only time span between 1387 and 1396/1398 when Sigismund was not in conflict with the rulers of Moldavia), even though it would be tempting to connect the matter of the estate(s) to the establishment of Angevine suzerainty over 
Within a few years (1395-1398), ${ }^{41}$ Stephen went from Sigismund's foe (Stephen's pro-Ottoman ${ }^{42}$ and pro-Polish enthronement had led to an instant royal Hungarian campaign against him) ${ }^{43}$ to his vassal (with lands in Transylvania, registered after the Nicopolis disaster). ${ }^{44}$ The Drágffys turned away from Sigismund. They lost almost all influence, until Matthias Corvinus' reign. ${ }^{45}$ The Drágffys' return to power largely coincided with the marriage between Mary, the daughter of King Matthias' trustee Bartholomew Drágffy ${ }^{46}$ and Alexander, the Moldavian heir of Stephen III, in the summer of $1489 .{ }^{47}$ After Sigismund of Luxemburg's grant to Stephen I, almost a century earlier (at any rate, a risky royal Hungarian decision for it also implied areas defined by strong feelings of local autonomy ${ }^{48}$ ), Stephen III was

Moldavia around 1377-1378 (see Ş. Papacostea, "Domni români şi regi angevini: înfruntarea finală (1370-1382)", Anuarul Institutului de Istorie şi Arheologie A.D. Xenopol, XXIII (1986), suppl., pp. 571-581). The interregnum of 1382-1386/1387 cannot be completely ruled out as potential candidate for an earlier dating of the donation (because - for instance - of the abovementioned Wallachian involvement in the Hungarian crisis). Yet the peculiar features of the region that included the Inner Szolnok County and the proximity of the estates of the growingly influential Dragoş family advocate caution.

${ }^{41}$ Constantin Rezachevici, Cronologia critică a domnilor din Ţara Românească şi Moldova (a. 13241881), I. Secolele XIV-XVI (Bucharest, 2001), pp. 460-463. His rule ended under misterious circumstances (possibly in battle against the Tartars). Nevertheless, like all Moldavian rulers (except for his successor Juga, dethroned and imprisoned by Mircea I in 1400) from Bogdan I († c. 1367) and until Alexander I (1400-1432), Stephen I was burried in the princely necropolis of Rădăuţi.

42 For Thomas Ebendorf (Chronica regem Romanorum (=Monumenta Germaniae Historica, Scriptores, NS, 18), edited by Harald Zimmermann, I (Hannover, 2003), p. 552), 1395 was the year when Moldavia came under Ottoman domination. According to Johannes Löwenklau (Annales Sultanorum Othomaniarum a Turcis sua lingua scripti, (Frankfurt-am-Main, 1588), p. 312), Stephen was the first ruler of Moldavia to accept Ottoman suzerainty. This had in fact occured under Peter I (c. 1390). His brother and - unwanted - successor - Roman I changed sides (1392-1394). Until, Stephen I came to power, Moldavia supported Sigismund and Mircea against the Turks (Al. Simon, "Bisericile Turcului: valahii lui Spandounes şi geneza Mitropoliilor Ţării Româneşti şi Moldovei”, Studia Universitatis Babeş-Bolyai. Theologia Orthodoxa , XVII (2010), 1, pp. 91-97, mainly at pp. 94-95).

43 Radu Manolescu, "Campania lui Sigismund de Luxemburg în Moldova (1395)", Analele Universităţii Bucureşti. Istorie, XV (1965), pp. 65-72.

${ }^{44}$ Without Stephen I's approval, Sigismund could not have made it, via the Danube Mounds, to Constantinople after Nicopolis. Moldavia controlled the Dniestr Mounds and partially the Danube Mounds (Al. Simon, "Annus Mirabilis 1387: King Sigismund, the Ottomans and the Orthodox Christians in the Late 1380s and Early 1390s", in Emperor Sigismund, pp. 125-150, at p. 143).

${ }^{45}$ For further information, see Richárd Horváth, "A Bélteki Drágfiak és a királyi udvar kapcsolata a Hunyadiak korában (1424-1490)", in A Szilágyság és a Wesselényi család (14-17. század), edited by G. Hegyi, A.W. Kovács (Kolozsvár, 2013), pp. 167-212.

46 Tibor Neumann, "Drágfi Bertalan politikai szerepe II. Ulászló király idején”, in A Szilágyság, pp. 213-236. He became voivode of Transylvania (1493), aiding Stephen III of Moldavia against the Jagiellonian brothers, Wladislaw II, Jan Albert of Poland and Sigismund (1497).

${ }^{47}$ M. Diaconescu, "Peţitorii nepoatei lui Ştefan cel Mare în 1517. Despre căsătoria lui Alexandru cu fiica lui Bartolomeu Drágfi”, Anuarul Institutului de Istorie A.D. Xenopol, XLIX (2012), pp. 55-70, at pp. 60-63.

${ }^{48}$ See in this respect Tudor Sălăgean, “ "Contrat» et «révolte»: traditions politiques dans le nord-ouest de la Transylvanie à la fin du règne de Sigismond de Luxembourg", and Szilárd Süttő, "Spuren einer vom niederen Adel ausgeübten Autonomie im Siebenbürgen des ausgehenden 14. Jahrhunderts", in A 
the first - known - ruler of Moldavia to receive (certainly two) estates in the Kingdom of Hungary.

Even though the issue was finalized almost a decade later, the first known official royal promise of an estate (i.e., a refuge castle) for Stephen III dates from $1482 .{ }^{49}$ It was the result of a series of negotiations initiated some three years earlier, in which Stephen I "played his part". On the new tombstone placed by Stephen III upon Stephen I's grave in Rădăuţi (1480), Stephen I was designated - a unique occurrence (among all contemporary tombstones) - as the one who had defeated the Hungarians at Hindău. ${ }^{50}$ Previously, no one in Moldavia (or in Jagiello Poland, Hungary's rival), had claimed that Stephen I had won at Hindău. Noteworthy enough, John Thuróczy (prior to 1488) and Antonio Bonfini (after 1486), Matthias Corvinus' chroniclers, paid almost equal attention to Sigismund's Moldavian campaign of January-February 1395 and to Matthias' largely ill-fated expedition from NovemberDecember $1467 .{ }^{51}$

Stephen III's lineage may prove relevant under our Sigismundian circumstances as well. ${ }^{52} \mathrm{He}$ was Bogdan II of Moldavia's illegitimate son (the most loyal to John Hunyadi of all Wallachian rulers ${ }^{53}$ ), the illegitimate at best son of Alexander I the Just, the son of Roman I (i.e. Stephen I's predecessor) and of his second wife, Radu I of Wallachia's sister or cousin..$^{54}$ In 1400 , less than a year after the death of Stephen I (Roman I's son from his first - Lithuanian- marriage), ${ }^{55}$ Mircea I, Radu I's son, ${ }^{56}$ enthroned the "Wallachian son" of Roman (Mircea's ally during his

Century in History (=Mélanges d'Histoire Générale, NS, II, 1-2), II. A Century in the History of Transylvania. The Later Crusades, Humanism, Church Union and Social Mobility at the End of the Middle Ages, edited by I. Drăgan, I.-A. Pop, T. Sălăgean, Al. Simon (Cluj-Napoca, 2008), pp. 161-170, and pp. 185-195.

${ }^{49}$ Cristian Luca, Al. Simon, "Documentary Perspectives on Matthias Corvinus and Stephen the Great", Transylvanian Review, XVII (2008), 3, pp. 85-112, at p. 88.

${ }^{50}$ Repertoriul monumentelor şi obiectelor de artă din timpul lui Ştefan cel Mare, edited by Mihai Berza (Bucharest, 1958), no. 59, p. 255.

${ }^{51}$ See also I.-A. Pop, Al. Simon, "The Venetian and Walachian Roots of the Ottoman-Hungarian Truce of 1468: Notes on Documents in the State Archives of Milan", in The Italian Peninsula and Europe's Eastern Borders. 1204-1669 (=Eastern and Central European Studies, I), edited by Iulian Mihai Damian, I.-A. Pop, M. Popović, Al. Simon (New York-Oxford-Basel-Frankfurt-am-Main-Vienna, 2012), pp. 283-302, at p. 285.

${ }^{52}$ For more information on his family, see Rezachevici, Cronologia critică I, pp. 513-515.

${ }^{53}$ See Sorin Iftimi, "La politique de Jean Hunyadi en Moldavie", în Between Worlds (=Mélanges d'Histoire Générale, NS, I-2), II. Extincta est lucerna orbis. John Hunyadi and his Time, edited by Ana Dumitran, Loránd L. Mádly, Al. Simon (Cluj-Napoca, 2009), pp. 365-378.

${ }^{54}$ E.g., Mark Whelan, Al. Simon, "A New Source on Moldavian Politics at the End of the Rule of Alexander I the Just”, Studii şi Materiale de Istorie Medie, XXXI (2015), pp. 149-160.

${ }^{55}$ Rezachevici, Cronologia critică, I, pp. 460-473. The - sadly - more than dubious genetic analysis of the remains of the voivodes buried in Rădăuţi prevents us from other assessments regarding Roman I and his family, Stephen I and his half-brothers included.

${ }^{56}$ Likely, unlike his brother and predecessor Dan I (whose downfall he apparently endorsed), Mircea I was Radu I's son from his second marriage. $17^{\text {th }}$ century sources claim that Mircea's mother (her name was recorded as Calinichia, but at a time when she was already a nun) was the daughter of Lazar 
short rule as sole voivode of Moldavia between 1391/1392 and $1394^{57}$ ) and took Moldavia under his Wallachian suzerainty. ${ }^{58}$ In the mid-1470s, Mircea, though quite voluntarily confused with nephew Vlad III the Impaller (Dracula) was regarded in a German pro-Habsburg treatise on the rise of the Turks as Dracola de Molda et Walachia, who had successfully fought against Sultan Bayezid I, victorious over Sigismund at Nicopolis in 1396. ${ }^{59}$ After (reluctantly) acknowledging that Mircea I had indeed enthroned Alexander I in Moldavia, Stephen, notorious for his Wallachian ambitions, ${ }^{60}$ took over, at least at the end of his rule, in his coat of arms

Hrebeljanović, the father of Stephen Lazarević. Lazar's youngest daughter, Theodora, wed Nicholas II, the son of Nicholas I Garai, approximately a year after (March-April 1387) his father had fallen in combat at the end of July 1386, apparently against Dan I. Dan then lost his life (within a month or two), fighting John Shishman, Tsar of Bulgarian Târnovo, whose son, Alexander, had married Dragana, Theodora's younger sister, earlier that same year (for these Balkan connections: John V. A. Fine, The Late Medieval Balkans: A Critical Survey from the Late Twelfth Century to the Ottoman Conquest (Ann Arbor, 19942), 387-389, 395-398). After Lazar's death at Kossovopolje (1389), Mircea I (who most likely however did not support him) claimed Podunavia (in the Serbian-Hungarian-Wallachian triconfinium), formerly in Lazar's possesion (Marian Coman, "Podunavia şi relaţiile sârbo-muntene în secolele XIV-XVI", in Istoria. Utopie, amintire şi proiect de viitor <Festschrift Andrei Pippidi>, edited by Ovidiu Cristea, Radu G. Păun (Iaşi, 2013), pp. 239-258). The absence of additional reliable sources advocates caution (see also A. Pippidi, "Despre Dan voievod: Rectificări cronologice şi genealogice", Studii şi Materiale de Istorie Medie, XXXI (2013), pp. 47-96, at pp. 72-73, for the dating of Mircea I's enthronement).

${ }^{57}$ Simon, “Annus Mirabilis 1387”, pp. 142-144. Roman I apparently also supported Sigismund against Wladislaw II Jagiello in their Podolian conflicts (Ilona Czamańska, Moldawia $i$ Woloszczyzna wobec Polski, Wegier i Turcji w XIV i XV wieku (Poznań, 1996), 56-57). He may have even lost his life during them. Immediately after his enthronement, Stephen I swore allegiance to Wladislaw II in early January 1395, with Sigismund's troops at his border. The preparations for the campaign had begun in December 1394 (Manolescu, "Campania lui Sigismund de Luxemburg”, pp. 65-66).

${ }^{58}$ Ş. Papacostea,"Aux débuts de I'état moldave. Considerations en marge d'une nouvelle source", Revue Roumaine d'Histoire, XII (1973), 1, pp. 139-158, at pp. 149-150. As part of the arrangement, Alexander conceded the direct connection between Hungary and the Danube Mounds (via the Oituz pass) to Mircea. The connection (part of the so-called Lower Country of Moldavia) had come under Moldavian control under Roman I, who had won the throne (1391/1392) against the sons of his brother, Peter I, the anti-Hungarian (and pro-Ottoman) ally of Mircea I and Wladislaw I, according to the arrangements of 1389-1390 (Simon, "Bisericile Turcului", pp. 94-95). Stephen III in his official chronicle had to admit Mircea I's role in the enthronement of Alexander I, though he omitted to mention the support he had received from Mircea's nephew, Vlad III Dracula, the son of Vlad II Dracul, in 1457 (Letopiseţul anonim al Moldovei, in Cronicile slavo-române din secolele XV-XVI publicate de Ioan Bogdan, edited by P.P. Panaitescu (Bucharest, 1959), pp. 6-23, at pp. 14-15).

${ }^{59} \mathrm{BStB}, \mathrm{CLM}, 14668, \mathrm{ff} .7^{\mathrm{r}}-43^{\mathrm{r}}$, at ff. $23^{\mathrm{r}}, 24^{\mathrm{v}}$

${ }^{60}$ Al. Simon, "From Wallachia to Dacia: International Politics and Political Ideology in the Last Decades of the Fifteenth Century", in Government and Law in Medieval Moldavia, Transylvania and Wallachia (=Studies in Russia and Eastern Europe, XI), edited byMartyn Rady, Al.Simon (London, 2013), pp. 91-100. 
the colours (green and gold) of Alexander Basarab,${ }^{61}$ married to Lady Clara de Ungaria ${ }^{62}$ who was probably Radu I's mother. ${ }^{63}$

Aside from Venetian "administrative records" related to the election of Matthias as king of Hungary in $1458^{64}$ or from John Hunyadi's Wallachian "usurpation" of $1447,{ }^{65}$ the Moldavian sources may provide the sole contemporary evidence for the princely Wallachian roots of the Hunyadi clan ${ }^{66}$. The chronicles of the Monastery of Putna, the necropolis of Stephen III and of his legitimate successors, ${ }^{67}$ recorded Matthias's death and spoke highly of him (though they

${ }^{61}$ Dan Cernovodeanu, Ştiinţa şi arta heraldică în România (Bucharest, 1977), p. 67. The Wallachian princely coat of arms was discovered only in 1920 when the so-called Grave 10 was found in the Princely St. Nicholas Church in Curtea de Argeş, more than four centuries after Stephen's colored coat of arms (1502). The identity of the deceased (usually deemed to have been Radu I or his brother and predecessor Wladislaw I) was not established until recently, following ${ }^{14} \mathrm{C}$ dating and DNA analysis (see Beatrice Kelemen, Adrian Ioniţă, Alexandru Simon, "Între Negru Vodă şi Prinţul Negru al Ţării Româneşti: mormântul 10 din Biserica Sfântul Nicolae Domnesc de la Curtea de Argeş", Anuarul Institutului de Istorie A.D. Xenopol, LI (2014), pp. 1-44). The visual identity between the two coats of arms (i.e. green and yellow/ gold, not red and white/ silver, Arpadian stripes) - separated by some 150 years (the very limit of medieval -oral - memory) is thus even more stiking.

${ }^{62}$ Pope Innocent VI recorded her in August 1360 as Clara de Ungaria, Wayuodissa Vlachie (Archivio Segreto Vaticano, Vatican City, Registra Avenionensia, [no.] 144. 1359-1360, f. 473²). Alike (some two decades later) the Duchy of Moldavia (a Latin rite state between 1370 and 1385/1386), Wallachia had received its first crown from the Papacy, from Pope Clement VI (c. late 1345-early 1347), about a decade after the marriage between Alexander, the son of Basarab I, and Clara, probably - because of her title and because of the post-Arpadian royal Hungarian context - an illegitimate daughter of Charles-Robert, the father of Louis I (B. Kelemen, A. Ioniţă, Al. Simon, "De la Biserica Argeş I la Biserica Argeş II: vremea Ţării Româneşti şi a Bisericii Sfântul Nicolae Domnesc", Anuarul Institutului de Istorie A.D. Xenopol, LII (2015), pp. 1-58). She was the mother of Louis' quandam suam consanguineam (Ancha) for whom, in winter 1346-1347, permission to marry Stephen Urosh V, the son of Stephen Urosh IV Dushan (recently crowned emperor) was requested from Clement VI (Österreichische Nationalbibliothek, Vienna (ÖNB), Codices, 2042, f. 1 ${ }^{\mathrm{r}}$, Sima Cirković, "O jednoj srpsko-ugarskoj alijansi”, Zbornik Radova Vizantološkog Instituta, XLIV (2007), 2, pp. 411-421, at pp. 420-421; this became a "very long engagement").

${ }^{63}$ Wladislaw I and Radu I were certainly brothers, according to Dan I's charter of 1385 for - interstingly enough - Tismana, Nicodimus' foundation (DRH, B, I, no. 7, pp. 19-22). According to Pope Urban V in 1370 (Acta Urbani P.P. V (1362-1370) (=Fontes, III, 11), edited by Aloisie L. Tăutu (Rome, 1964), nos. 180-d, pp. 305-308; no. 193, p. 237). Clara, the mother of Anna of Bulgarian Vidin (the wife of John Stratsimir, John Shishman's half-brother and rival) and of Ancha of Serbia (the wife of Stephen Urosh V), was Wladislaw I's noverca (meaning primarily stepmother, but also adoptive mother and even mother-in-law). Alexander certainly had a son, Voislav (a typically Serbian name, never used afterwards by the Wallachian elites), buried next to him in Curtea de Argeş, according to Voislav's tombstone discovered - likewise - in 1920 (see also Virgil Drăghiceanu's notes in Buletinul Comisiunii Monumentelor Istorice, X-XVI (1917-1923), pp. X, 264).

${ }^{64}$ Stefano Magno, Annali veneti et del mondo, I-IV [1433-1478] (=ÖNB, Cods. 6214-6217), III [14571468 (=Cod. 6216)], Ad annum 1457 [More Veneto 1458], f. $6^{\mathrm{r}}$. Matthias was [...] d'origine humile de progenie de Valacchia [...].

${ }^{65}$ DRH, D, I, no. 286, p. 394; Pall, "Intervenţia lui Iancu de Hunedoara”, pp. 1069-1070.

${ }^{66}$ In spite of numerous studies, this "detail" has passed unnoticed until quite recently.

${ }^{67}$ See also Ştefan S. Gorovei, Maria-Magdalena Székely, Princeps omni laude maior. O istorie a lui Ştefan cel Mare (Putna, 2005), pp. 9-13, 75-76. 
emphasized "his Moldavian defeat" at Baia in December 1467) ${ }^{68}$ All other deaths mentioned in these chronicles belonged to members of the House of Bogdan or to their relatives (by marriage). ${ }^{69}$

The Putna chronicles acknowledged in effect Matthias as a relative of the House of Bogdan, ${ }^{70}$ in a manner quite like that of Stephen III's own acceptance of Dragoş and of his sons as the first voivodes of Moldavia. ${ }^{71}$ Fact or fiction, ${ }^{72}$ the

${ }^{68}$ The texts were last edited in Cronicile Slavo Române (they predate the final preserved version of the Stephen III's "official chronicle", though the latter ended with the year 1507): Letopiseţul de la Putna I, pp. 43-52 (1359-1526), at pp. 49, 50; Letopiseţul de la Putna II, pp. 55-66 (1359-1519), at pp. 62, 64.

${ }^{69}$ Such as Ivan Ivanovitch, the son of Ivan III of Moscow, married to Helena, the daughter of Stephen III and of Evdochia of Kyiv. He died a month before Matthias. Yet the chronicles (Putna I and II) recorded his death after that of Matthias. Stephen III's so-called "official chronicle" mentioned none of the two deaths and further omitted - in comparison to the deaths recorded in the two chronicles from Putna - the death of the influential metropolite of Moldavia, Theoctist I (1477), as well as that of Stephen III's first wife, Evdochia of Kyiv, who had passed away when Matthias entered Moldavia in November 1467.

${ }^{70}$ With the mention of Stephen III's death, these chronicles basically ended. Putna I briefly mentioned the enthronments of Bogdan III (1504) and Stephen IV (1517), Stephen IV's success over the Tartars (1519), the Ottoman victories over the Hungarians at Belgrade and Mohács (1521 and 1526) and the death of Peter, Bogdan III's son and Stephen IV's (half?) brother ( $25^{\text {th }}$ of September 1526). The Putna II mentioned the enthronement and the death of Bogdan III, as well as the enthronement of Stephen IV, ending with the narration of Stephen IV's victory (i.e., of the captains of the - at that time approximately ten year old prince) over the Tartars. Not even the death of Mary Voichiţa (Branković), the last wife of Stephen III and Bogdan III's mother (1510), was recorded, though she was buried in Putna, like her mother, Mary Despina (the wife of Radu III, the son of Vlad II). Her death in 1500 had been duly registered by both chronicles.

${ }^{71}$ In Stephen III's "official chronicle", Ladislas/ Laţcu (c. 1367-c. 1373), the first Moldavian monarch (as Latin rite duke since 1370) was deemed the son of Sas, the son of Dragoş, the (first) founder of Moldavia (in 1359. Laţcu had - thus - ruled before Bogdan I (who in fact ruled just before Laţcu, between c. 1363 and c. 1367). On the tombstone placed - similarly in Rădăuţi - by Stephen III on Laţcu's grave no mention was made regarding Laţcu's father (In the chronicles from Putna, Laţcu was correctly placed after Bogdan I, as his son). All preserved (new) princely tombstones were placed in Rădăuţi by Stephen III (for, in the chronological order of their installement, Roman I, Laţcu, Bogdan, Alexander I's maternal brother, Bogdan I and Bogdan, Alexander I's son) between mid-December 1479 and the end of January 1480, except for Stephen I's tombstone, with its special "Hungarian mention". The latter was installed in the second half of May 1480 (Repertoriul monumentelor şi obiectelor de artă, nos. 53-57, pp. 249-254; no. 59, pp. 255-256; we note in addition that Stephen III deemed Bogdan, Alexander I's brother, as his grand-father, though - officially - the father of Stephen's father, Bogdan II, was Alexander I).

${ }^{72}$ Three matters might be of relevance in this respect, as the (medieval) question is (was) not so much what truth lay behind such relations, but what could have been accomplished through them. 1. "Like" the Hunyadis - Stephen III had Serbian claims related to both Hilandar, on Mount Athos (1466), and Podunavia (1475), prior to his marriage to Mary Voichiţa in 1478 (Luca-Simon, "Documentary Perspectives", pp. 87-88). The only justification for them was on Wallachian genealogical soil, on his paternal side. His mother, Oltea, was from the Lower Country of Moldavia and was never designated - including by her son - a lady (Gorovei-Székely, Princeps omni laude maior, pp. 9-10). 2. According to Jan Długosz, a sister of John Hunyadi was given into marriage to - the much younger - Alexander II of Moldavia, a marriage "below the station" at the time of the Hunyadis (unlike in the case of the two Hunyadi marriages of Vlad III, the first one with a close relative of Matthias, an unknown cousin 
princely Wallachian roots of the sons of Alexander I the Just of Moldavia, as well as of Voicu of Hunedoara were endorsed by medieval Moldavian monastic sources. ${ }^{73}$

Wallachian Dynastic Alliances. Sigismund of Luxemburg was most aware of Wallachian princely "genealogies"74. The three known daughters (Anchal Alexandra, ${ }^{75}$ Anna and Elisabeth) of Alexander of Wallachia and of Clara of Hungary ${ }^{76}$ had wed: (1) Stephen Urosh V of Serbia (c. 1346-1347), ${ }^{77}$ (2) John Stratsimir of Bulgaria (c. 1353-1354) ${ }^{78}$ and (3) Wladislaw II of Oppeln (c. 13541355). ${ }^{79}$ The daughter of Stratsimir and Anna, Dorothea (King Louis I' favourite), had

or even an ilegitimate daughter of John, and the second with the king's maternal cousin, Justine Szilágyi). This calls for dynastic (family) reasoning (see Al. Simon, "Propaganda and Matrimony: Dracula between the Hunyadis and the Habsburgs", Transylvanian Review, XX (2011), 4, pp. 80-90). 3 . The Putna I and II chronicles remain the only contemporary written Moldavian sources to emphasize Transylvania in the politics of Stephen III through the gifts he received and the gifts he made (Putna I, pp. 49-50; Putna II, pp. 62, 65): (1) immediately after/ sometime after the battle of Baia (according to the chronicles) Matthias gave Stephen estates in the Land of Transylvania (Ardeal in the original, based on the Hungarian name of the province); (2) in 1497, Stephen made numerous gifts to his co-father-inlaw, Bartholomew Drágffy, voivode of Transylvania, who had come to aid him against King John Albert of Poland; according to Maximilian I of Habsburg (1498), at that time, Stephen controlled half of Hungary, of Matthias' royal legacy (Correspondencia de Gutierre Gomez de Fuensalida, embajador en Alemania, Flandes é Inglaterra (1496-1509), edited by Jacob Fitz-James Stuart de Berwick-Alba (Madrid, 1907), p. 21).

73 This literally meant claiming part of Hungary for Stephen and chiefly his successors by right of blood, as King Matthias' relatives. John Corvinus died in October 1504, three months after Stephen's death. The male line of the Hunyadi family died out by spring 1505 . Post- 1526 events tend to support this idea. Based on Eugenius IV' decision of 1436, Moldavia (and not Wallachia) certainly had the Greek rite ecclesiastical rights over the eastern parts of Hungary (Acta Eugenii PP IV (1431-1447) (=Fontes, III, 15), edited by Georgio Fedalto (Rome, 1990), no. 421, pp. 229-230).

${ }^{74} \mathrm{We}$ focus under the circumstances on the relations established prior to 1398-1399. For King Sigismund's knowledge towards the end of the reign, see M. Whelan, Al. Simon, "The Moldavian Lady and the Elder Lords of the East", Transylvanian Review, XXIV (2015), 3, pp. 113-129.

${ }^{75}$ Ancha was recorded also as Helena or Slava (Mauro Orbini, Il regno degli Slavi (Pesaro, 1601), p. 267; Giacomo di Pietro Luccari, Copioso ristretto degli annali di Ragusa (Venise, 1605), p. 60).

${ }^{76}$ The three daughters are listed in the - (needless to say) apparent - chronological order of their marriages. To this end, we have given the approximate dates based on the few preserved sources.

77 ÖNB, Cod. 2042, f. $1^{\text {r }}$. The letter sent by an unnamed (in the Viennese preserved medieval copy) Hungarian prelate to the pope suggest that - at least by proxy - the marriage was a fait accompli when the bishop asked Clement VI not to interfere with Louis I' decision. On the other hand, it seems that the marriage was celebrated at a much later date because of Stephen Dushan's changing policies (e.g. Monumenta Serbica spectantia historiam Serbiae, Bosnae, Ragusae, edited by Franz Miklosich (Vienna, 1858), no. 127, p. 147; Stephen Dushan's charter for Ragusa, issued in 1349).

${ }^{78}$ Ivan Božilov, Фамилията на Асеневичи (1186-1460). Генеалогия и просопография (Sofia, 1994), pp. 200-202.

${ }^{79}$ In this matter (highly debated at the end of the 1990s), see also Maciej Salamon, "Ladislaus von Oppeln: ein schlesischer Herzog zwischen der katolischen und der orthodoxen Welt", in Medieval Christian Europe: East and West. Traditions, Values Communications, edited by Vassil Gjuzelev, Anisava Miltenova (Sofia, 2002), pp. 518-527, at p. 521, note 20. 
wed Tvrtko I (1374) $)^{80}$, the first king of Bosnia, Sigismund's southern nemesis. ${ }^{81}$ Ágnes-Elisabeth, the child of Wladislaw II of Oppeln and Elisabeth, was married to Jobst of Moravia (1372), Sigismund's - (most) unwanted - paternal cousin. ${ }^{82}$ In addition to these marriages (that basically connected the so-called "Visegrád group" to the "Belgrade-Vidin-Severin group" ${ }^{83}$ ), there was already an abundance of Wallachian princely offsprings ${ }^{84}$ that competed for the throne (the same applied for Moldavia, in particular after the death of Peter I, around $1391^{85}$ ). More were to come until the end of Sigismund of Luxemburg's reign, following the death of Mircea I (1418). Mircea I had seemingly fathered an impressive number of bastards (as the late Byzantine chronicles noted with undisimulated satisfaction). ${ }^{86}$ Sigismund's charters never listed Voicu and his family relatives of the House of Basarab. ${ }^{87}$ Still,

${ }^{80}$ See also Mór Wertner, A középkori délszláv uralkodók genealogiai története (Temesvár, 1891), pp. 218-220, 226-227.

${ }^{81}$ Fine, The Late Medieval Balkans, pp. 391-392; Mályusz, Kaiser Sigismund, pp. 24-26, 31.

${ }^{82}$ Dieter Veldtrup, Frauen um Herzog Ladislaus ( $\left.\uparrow 1401\right)$ : Oppelner Herzoginnen in der dynastischen Politik zwischen Ungarn Polen und dem Reich (Warendorf, 1999), pp. 53-60, 80-86. One information, for which I am indebted to Professor Petr Elbl, might be relevant in this context. Apparently, in the 1390s, a Moravian noble fought against the Turks in Wallachia. He was created a knight by Mircea (Wallachia seemingly had its own order of knights prior to the creation of the Order of the Dragon), who gave him a ring on this occasion (for the ring, in private property, and its depiction: Heinz Rohlik, "Rohlik", Deutsches Geschlechtsbuch, LX (CCXIX) (2007), pp. 155-174, here at p. 166).

${ }^{83}$ The second lesser-known group predated the first. It consisted of the relatives and offsprings of Stephen Milutin, Basarab and Michael Sishman, pro-Tartar allies during Charles-Robert of Anjou's combats for Hungarian power. The wife of John Alexander, tsar of Bulgaria (since 1331), was Theodora, Basarab's daughter. The tsar's sister, Helena, had wed the new king of Serbia, Stephen Dushan, in 1332. The "Visegrád group" (Hungary-Poland-Bohemia) appears to have been created by Charles-Robert (1335-1339) also as response to this southern dynastic alliance. Noteworthy enough, the marriage between Alexander, the son of Basarab, and Clara (his second wife; given also Voislav's name, Alexander's first wife had been of Serbian origins) was concluded at some point between the main dates of the constitution of the "Visegrád group", either prior or after the Byzantine sponsored Turkish attack on Bulgaria and Wallachia in 1337-1338 (for the main extant sources, see KelemenIoniţă-Simon, "De la Biserica Argeş I la Biserica Argeş II", pp. 48-51).

${ }^{84}$ Not only Constantinople, Adrianople or Krakow possessed a "reservoir" of princely Wallachian candidates (hostages), but also Buda (Ferenc Forgach, Rerum Hungaricarum sui temporis commentarii libri XXII (Bratislava-Kosice 1788), p. 275).

${ }^{85}$ For both states, see the overview in Rezachevici, Cronologia critică, I, pp. 78-84, 446-471.

${ }^{86}$ E.g. [Michael] Dukas, Istoria turco-bizantină (1341-1462), edited by Vasile Grecu (Bucharest, 1958), p. 250. This attitude was chiefly due to Mircea I's involvement during the Ottoman civil war (1402-1413). Still, Michael I too was viewed as morally decayed in the same Byzantine environment. ${ }^{87}$ Prior to Voicu, only four other Wallachians are known to have been courtiers: Carapciu of Recass (in the Banate <of Hungary>), whose family had fled from Wallachia during the conflict between Louis and Alexander (1345-1347) and the sons of Sas, Balc (Baliţă), Drag and John (I. Drăgan, Nobilimea românească din Transilvania. 1440-1514 (Bucharest, 2000), p. 423). The safest assumption would be that Voicu had, at least, the royal Hungarian relevance of Carapciu. As to his princely Wallachian ties, because Voicu was seemingly never employed as a candidate for the Wallachian throne, they must have been on his mother's side, not on his father's (Şerb). The family's policy towards Wallachia indicates that their Basarab ties followed the lineage(s) of Wladislaw I, Dan I and Vlad I (Octavian Iliescu, "Vlad Ier, voïvode de la Valachie: le règne, le sceau et les monnaies", Revue Roumaine d'Histoire, XXVII (1988), 1-2, pp. 73-105). This would also suit Nicolaus Olachus' "story". According to himself, 
the grant of the Hunyad estate to Voicu (October 1409) ${ }^{88}$ predated by only months a new conflict between Sigismund and Mircea. By May 1410, Mircea had attacked Transylvania. ${ }^{89}$ The Polish defeat of the Teutonic Knights at Grünwald (July) halted the planned Hungarian campaign against Mircea. ${ }^{90}$ The death of Rupert of Wittelsbach, King of the Romans (May) further distracted Sigismund from the Wallachian issue. He had to compete with Jobst for Rupert's succession (SeptemberOctober 1410). At first, he lost in front of his cousin. Then, Sigismund prevailed. ${ }^{11}$

In an age of few coincidences, the grant of Hunyad to Voicu narrowly preceded the official outbreak of a conflict between Sigismund and Mircea. ${ }^{92}$ Earlier, the grant of the estate(s) in the Inner Szolnok County to Stephen I had chronologically - stood at the beginning of the break between the Dragoş family and Sigismund. ${ }^{93}$

Olachus was related to the Hunyadis on his paternal side via John's otherwise unknown sister Marina (Ungaria.Atila, edited by Antál Gyöngyvér (Iaşi, 1999), pp. 87-89).

${ }^{88}$ The final (privilegial) charter for the estate was issued on February 10, 1410 (Lupescu, "Matthias Hunyadi', p. 39), consequently further reducing the distance between the two events (see below).

${ }^{89}$ MOL, DL 73910 (May 8, 1410; edited in DRH, D, I, no. 113, p. 183; calendared in ZsO, II-2. 1407 1410, edited by E. Mályusz (Budapest, 1957), no. 7573, p. 355). Bologa (refered to also as Sebeswar or Kalathazeg, a rather confusing name) was generally deemed the Hunyad castle donated to Mircea (primarily because the village Şaula, Saluasara in the deed, was part of the estate). Bologa was again a royal castle in 1412 (Dezső Csánki, Magyarország történelmi földrajza a Hunyadiak koraban, V (Budapest, 1913), pp. 299-300; cited by Pataki, “Ceva despre relaţiile Țării Româneşti”, p. 425).

${ }^{90}$ In relation to our topic (given also the special "anniversary features" of the age, i.e., the Warsaw Pact vs NATO/ "battle of nations"), see also Ştefan Ştefănescu, "Participarea românilor la lupta de la Grünwald (15 iulie 1410)", Studii. Revistă de Istorie, XIV (1961), 1, pp. 5-22.

${ }^{91}$ For the context, see also Jörg K. Hoensch, Kaiser Sigismund: Herrscher an der Schwelle zur Neuzeit, 1368-1437 (Munich, 1996), pp. 263-266; Mályusz, Kaiser Sigismund, pp. 72-76.

${ }^{92}$ Apparently, no connection was previously established between the two events, possibly also because the Wallachians who had attacked Transylvania and had to be punished were deemed to have come from Moldavia. Yet Moldavian attacks on the realm usually targeted the Maramureş (e.g., ZsO, II-1. 1400-1406, edited by E. Mályusz (Budapest, 1956), no. 3035, p. 357; no. 5152, p. 653; II-2, no. 5504, p. 32; III. 1411-1412, edited by E. Mályusz, I. Borsa (Budapest, 1993), no. 1093, p. 295; apparently, in spite of their old feud, the House of Bogdan supported the House of Dragoş during the latter's conflict with Sigismund). For the context: C. Rezachevici, "Implicarea Giurgiului în relaţiile lui Mircea cel Bătrân cu Polonia", Revista Istorică , NS, XIII (2002), 3-4, pp. 149-159 (the last three, 1403, 1411, 1415 , of the four major Wallachian-Polish arrangments under Mircea, were concluded in Giurgiu on the Danube, at a safe distance from the Hungarian border).

${ }^{93}$ See N. C. Tóth, "Szász vajda utódainak felemelkedése és bukása. A család vázlatos története 13651424 között", in A Szilágyság, pp. 135-166, at pp. 138-140, 142-143. The origins of the break between them and Sigismund might have dated back to 1390 (when they lost the countship of the Szeklers). Because of the key Constantinople mission entrusted to the brothers by the king in 1391 (Papacostea, "Byzance et la création de la Métropole", pp. 137-139), 1396 would however be the soonest estimate. That year, Balc and Drag lost Sătmar, the county that together with Maramureş and Ugocsa had formed the foundation of their power, since the mid-1370s. At any rate, in spring 1398, the relations between the Dragoş and Sigismund were no longer those from 1386-1387. 
After Nicopolis and the Diet of Timişoara (1396-1397) ${ }^{94}$ Sigismund had deemed it wise to establish his vassals voivodes of Wallachia and Moldavia in the Voivodate of Transylvania, and not so far apart from each other (if we are to fully embarce the commonly accepted identification of Mircea's Hunyad with Bologa, west of the city of Cluj). ${ }^{95}$ Sigismund would have thus supplemented the forces of his proven loyal trustee Stibor of Stiboricz, voivode of Transylvania, ${ }^{96}$ and set a convenient distance between Moldavia, Wallachia and the - new in the case of Mircea I - Hungarian estates of their voivodes (once again, if Hunyad was not Hunyadi Hunedoara).$^{97}$

Sigismund's decision backfired in part also because of the general context. ${ }^{98}$ A rebellion broke out, supported by the Dragoş family as well. ${ }^{99}$ The Moldavian

${ }^{94}$ Polish-Moldavian relations prevent us from dating the reconciliation between Sigismund and Stephen I immediately after the royal campaign in Moldavia, though the king claimed a complete victory. Additionally, by late spring 1396, Mircea lost control over a significant part of Wallachia, occupied by Vlad I, supported by Wladislaw II; Vlad was eventually defeated and captured by voivode Stibor in winter 1396-1397 (Rezachevici, Cronologia critică, I, pp. 82-83). Because at the beginning of 1399, the Transylvanian representative of Mircea I excused himself for not knowing the exact limits of the estate of the Hunyad land (DRH, D, I, no. 104, p. 171), we must assume that both royal grants (from Mircea and Stephen) were related to the Diet of Timişoara convened by Sigismund in October 1397. The high offices held by non-Hungarians was one of the main points on the agenda of the Diet. The "ethnic" context of the donation of the estates was rather tense.

${ }^{95}$ Because no reference was made to the Hungarian wife of Mircea I and her rights in relation to the Hunyad castle of 1398 and because the Hunyad castle (if identified with Bologa) had previously been held by the voivode of Transylvania (Pataki, "Ceva despre relaţiile Țării Româneşti", p. 425), we have to presume that this estate was not part of the "dowry" of Mircea I's wife, but a proper royal grant for the voivode of Wallachia. The Bánffy-Losonczi family (to which his wife was also presumed to be related) only acquired Bologa towards the end of Sigismund's reign (i.e., in 1435).

${ }^{96}$ Daniela Dvoráková, A lovag és királya: Stiborici Stibor és Luxemburgi Zsigmond (Bratislava, 2009). Stibor was among the high-ranking non-Hungarian officials explicitly "spared" in autumn 1397 by the Diet of Timişoara. We consequently underline that the Diet of Timişoara most likely did not view any of the Wallachian voivodes, who were granted estates in the Hungarian kingdom, as an "etnic" threat to the stability of the realm (besides, Mircea's wife was a proper Hungarian lady).

${ }^{97}$ In Mircea's case, the motivation for the donation of Hunyad (Bologa?) may have also been related to the threats revealed by Vlad's rule, that touched, if not engulfed, also Amlaş and Făgăraş (see also M. Diaconescu, "The Relations of Vassalage between Sigismund of Luxemburg, King of Hungary, and Mircea the Old, Voivode of Wallachia”, Mediaevalia Transilvanica, II (1998), 2, pp. 245-282, at pp. 255-257, 265-271). The royal grant for Mircea in the Cluj County would be even more telling if the Bran castle near Braşov had been entrusted to Mircea by Sigismund following their treaty of March 1395 (concluded in the same city of the Transylvanian Saxons). Bran was certainly Mircea's in 1412 when Stibor deemed it to be in foreign hands (see also Panaitescu, Mircea cel Bătrân, p. 235, note 19). Bran in south-eastern Transylvania was a significantly more delicate possession than Bologa in the north-west, for it largely controlled Hungarian-Wallachian trade.

98 The absence of other known relevant sources limits any modern interpretation of his decisions, in relation to Moldavia, under Alexander I's rule (on this matter, see more below).

${ }^{99}$ R. Popa, Țara Maramureşului în veacul al XIV-lea, edited by A. Ioniţă (Bucharest, 19972), pp. 231, 236-238. The Drágffys' main local rivals were count Peter Perény and Theodore Koriatović. The latter's family was related to the House of Bogdan. Theodore had been supported by Roman I (and Sigismund), against Wladislaw II in 1393-1394 (Czamańska, Moldawia $i$ Woloszczyzna, pp. 56-57). 
grant was not renewed, not even after Mircea enthroned Alexander I. ${ }^{100}$ Irrespective of the Hunyad's identity, Mircea himself kept Hunyad for a decade. ${ }^{101}$ Additionally, when a new domestic crisis was blooming (1399-1400), ${ }^{102}$ Sigismund had major problems - especially in the Zala County - because of the behavior of Mircea's wife on her estates (Mircea's Hungarian wife was most likely related to the Cilly family, to which Sigismund's and Wladislaw II Jagiello of Poland's second wives belonged). ${ }^{103}$

Sigismund of Luxemburg and the Rise of the Hunyadis. In this border context, the Hunyadis in the Land of Haţeg seem to have been King Sigismund's

100 The charter of May 1398 did not contain any reference to the actual estate(s) and its/ their name(s). It dealt only with the matter of Stephen I's legal represenative (DRH, D, I, no. 102, p. 169). Any assumption regarding the estate(s), its/ their extent and location would be speculation. Furthermore, the Moldavian raids in the Maramureş area during the royal Hungarian crisis made a renewal of the grant under Alexander I unlikely (see also N. Iorga, "O mărturie din 1404 a celor mai vechi moldoveni", Analele Academiei Române. Memoriile Secţiunii Istorice, $3^{\text {rd }}$ series, VI (1926), pp. 69-72).

101 Csánki, Magyarország történelmi földrajza, V, p. 300. Pataki ("Ceva despre relaţiile Ţării Româneşti”, p. 425) challenged such a possibility (not even taken into account earlier) by simply stating that the mention of Bologa as royal Hungarian castle in the year 1412 was no evidence that Mircea I of Wallachia had lost the Transylvanian estate (even though this was precisely the obvious case).

102 Zala vármegye története. Oklevéltár, II. 1364-1498, edited by Imre Nagy, Dezső Véghely, Gyula Nagy (Budapest, 1890), no. 117, pp. 298-299; Panaitescu, Mircea cel Bătrân, pp. 60-61.

103 The hypothesis was first voiced by Panaitescu (Mircea cel Bătrân, pp. 59-61) in the 1940s. The key evidence in this respect were the lands in the Zala County, largely controlled by the Cilly. This interpretation, otherwise, generally accepted, was challenged chiefly by Pataki in the $1950 \mathrm{~s}$. He attempted to "counteract" Zala with Bologa, though no mention of Mircea's wife was made - in the sole known charter on the issue from 1399 - in relation to Hunyad castle. Considering also that (1) in 1400 , when he wrote in anger to Mircea's wife, Sigismund did not call her by her name (Zala vármegye története, II, no. 117, pp. 298-300), the Tomay (Tomaj) estate mentioned in the same context was connected to the kindred to which the Bánffys belonged (Pataki, "Ceva despre relaţiile Ţării Româneşti', p. 428), and that (2) the major Hungarian feudal fall after 1397 was that of the Láckfy family (P. Engel, "Zsigmond bárói: rövid életrajzok", in Müvészet Zsigmond király korában 1387-1437, edited by László Beke, Ernő Marosi, Tünde Wehli, I. Tanulmányok (Budapest, 1987), pp. 405-458, at pp. 427-430), we cannot rule out a "Cilly genetic foundation" in the case of Mircea's Hungarian wife (see also Heinz Dopsch,"Die Grafen von Cilli: ein Forschungsproblem?", Südostdeutsches Archiv, XVII-XVIII (1974-1975), pp. 9-49), well-embedded however in the power relations of Hungarian clans that shaped policies in the realm prior to Sigismund's rise in 1387.

Although we cannot tell when it was celebrated exactly, the plausible Cilly marriage of Mircea I certainly predated those of the two kings. The earliest - uncertain - mention of Michael (the son of Mircea and of his Hungarian wife) as his father' associate in 1391 suggests that the marriage was concluded at the time of Sigismund's contested enthronement (in his "Despre Dan voievod", pp. 5152, 81; Pippidi even presumed that Mircea's rule began already in March 1386; hence, Mircea, and not Dan I, would have been the voivode who - according to von Müllich - killed Garai). 
safest "Wallachian gamble" 104 , and - obviously - not Stephen I ${ }^{105}$ or Mircea I, the self-styled blood-relative of King Wladislaw Jagiello, ${ }^{106}$ as well as - conveniently for John Corvinus in the post-Cilly context of his days ${ }^{107}$ - the father of John

${ }^{104}$ For an overview: I. Minea, Principatele române şi politica orientală a împăratului Sigismund (Bucharest, 1919); Pippidi, "Despre Dan voievod", passim. Vlad II Dracul, Mircea's illegitimate son, and Dan II (III according to Pippidi), another illegitimate son of Mircea (and seemingly not the son of Dan I, Mircea I's half-brother as usually presumed) in the 1420s and then 1430s proved also quite (given the medieval circumstances) loyal. In comparison to them, we must note that no known member of the Hunyadi family was in fact "pushed" towards the Wallachian throne, even after the death of Sigismund and the Ottoman campaigns "guided" by Vlad II into the realm (1437-1438), when John and his younger - half - brother John (Jovan/Ivaşcu) were appointed bans of Severin (1439).

After that moment, John ceased to be called John the Wallachian in official Hungarian records (see also Lupescu, "Matthias Hunyadi", p. 42). Given his time in royal service, John's earlier designation as the Wallachian cannot be explained only by ethnic criteria in the context of his elevation to the rank of ban of Severin. He had spent too much time in Hungarian administration (fifteen years) in order for the Wallachian designation to become obsolete prior to 1439 (still, as a court knight, from 1434 onwards, he had been named Johannes Olah de Hunyad; Drăgan, Nobilimea românească, p. 424; the emphasis placed on the Wallachian was futile, as long as he was further named of Hunedoara). The most plausible explanation seems of political nature. Once John became a high official (and real baron) of the realm (Kubinyi, Matthias Rex, p. 13), Wallachia as a "career option" was out of the question, irrespective of how meagre or strong John's ties to the Basarabs were). Still, as regent of Hungary (1447), John personally pushed for more: the throne of Wallachia (Pall, "Intervenţia lui Iancu de Hunedoara", passim). But John had to pull back and enthrone his relative, Wladislaw II.

105 Stephen I was also open to "Catholic temptation" (Renate Möhlenkamp, "Ex czeretensi civitate: Randnotizen zu einem in Vergessenheit geratenes Dokument", Anuarul Institutului de Istorie şi Arheologie A.D Xenopol, XIX (1982), pp. 105-130). Both his father (Roman I) and his uncle (Peter I) had been Latin rite Christians prior to 1386-1387, under the influence for their powerful mother, Margarete of Siret (Acta Gregorii P.P. XI (1370-1378) (=Fontes, III, 12), edited by A.L. Tăutu (Rome, 1966), no. 248, pp. 493-494). Alexander I, Stephen I's younger half-brother, also used to be a Latin rite Christian (Anton Kern, "Der Libellus de notitia Orbis Johannes III (de Galonifontibus?) O.P. Erzbischofs von Sultanieh", Archivum Fratrum Praedicatorum, VIII (1938), pp. 82-123, at p. 104, note 12). Such "vulnerabilities" did not help settle the conflict between Byzantium (i.e.. the Ecumenical Patriarchate of Constantinople) and Moldavia, although Sigismund apparently used his Byzantine credit to better relations, after he reconcilied with Stephen (Simon, "Annus mirabilis 1387”, p. 145).

${ }^{106}$ In 1411, Mircea addressed Wladislaw as his blood relative. Even under medieval circumstances, this designation hardly matched a relation established through wives. However, a direct Moldavian genealogical link between Mircea and Wladislaw was impossible (Panaitescu, Mircea cel Bătrân, p. 59; Whelan-Simon, "A New Source”, pp. 154-155). Mircea's exaggeration must have been rooted in the wives of the two monarchs. His Hungarian lady had given birth to Mircea's heir and associate-ruler of Wallachia, Michael I, "his blood". Anna was expected to give birth to Wladislaw II's much needed son and heir (by the time of the Polish-Wallachian treaty of 1411, she had given birth only to Hedwig). Besides, the northern connections of Mircea were strong enough to support in 1416 a planned matrimonial union between him and Witold of Lithuania, Wladislaw's cousin ( $\mathrm{ZsO}, \mathrm{V}$. 1415-1416, edited by I. Borsa (Budapest, 1997), no. 2023, pp. 545-546). Mircea was still married to Michael's mother, who outlived him. Anna, Witold's wife, passed away only in 1418. Their only daughter, Sophia, was married to Vasili I of Moscow. The only potential wedding must thus have been between Michael, who had two sons at the time of his death in 1420, and a relative of Witold.

${ }^{107}$ After Ladislas Hunyadi, Matthias' elder brother, had Ulrich II of Cilly executed in November 1456, the family, deprived already of male and female offsprings, died out (Johannes Grabmayer, "Das Opfer war der Täter. Das Attentat von Belgrad 1456 - über Sterben und Tod Ulrichs II. von Cilli”, 
Hunyadi and the husband of a member of the Cilly family. ${ }^{108}$ Seemingly, less wellrooted in the growing House of Basarab than other Wallachian "applicants" in quest for Hungarian royal grace, ${ }^{109}$ Voicu was apparently never prompted towards Wallachia's throne, but was entrusted with a key-station at its Hungarian border. ${ }^{110}$ Endowed with Hunyad, he "cut" the princely web that spread on both slopes of the Southern Carpathians, connecting the Banate of Severin, Oltenia (i.e. the Land of Severin), the Duchies of Amlaş and Făgăraş and the Land of Haţeg. ${ }^{111}$ The son of the natural son of Sigismund of Luxemburg (according to Hungarian rumors), ${ }^{112}$ of Stephen Lazarević (in Serbian tradition) ${ }^{113}$ and of Mircea I (following Corvinus-Cilly

Mitteilungen des Instituts für Österreichische Geschichtsforschung, CXI (2003), pp. 286-316). Ulrich's
widow, Catherine, the daughter of George Branković, died in 1491 . By the end of the century, there
was no one left to challenge the "Corvinus adaptation" of the history of the counts. By then, John
Corvinus had also won the favour of Maximilian I of Habsburg (Paul Gwynne, "Tu alter Caesar eris:
Maximilian I, Vladislav II, Johannes Michael Nagonius and the renovatio Imperii", Renaissance
Studies, X (1996), 1, pp. 56-71). Maximilian was Frederick III's son. Frederick and John Hunyadi had
been Ulrich II of Cilly's main enemie (Konstantin Moritz Ambrosius Langermaier, Erzherzog Albrecht
VI. von Österreich: ein Fürst im Spannungsfeld von Dynastie, Region und Reich (=J.F. Böhmer,
Regesta Imperii, suppl. XXXVIII) (Cologne-Weimar-Vienna, 2015), pp. 443-447).
108 Basically (prior to the "Ottoman rediscovery" of Mircea I by Johannes Löwenklau in the 1580s),
the Cilly marriage of Mircea I and his alleged fatherhood of John Hunyadi support each other in the
context of this altered version of the chronicle of the by then extinct counts of Cilly.
109 For an overview (from 1418 onwards), see Pippidi, "Despre Dan voievod", pp. $82-93$.
${ }_{110}$ Voicu died (between 1414 and 1419) most likely before Mircea's death in 1418 (see Kubinyi, Matthias Rex, p. 8; Lupescu, "Matthias Hunyadi', p. 40). Because of his location, he should have played a major role in the subsequent events. The Argeş castle was occupied by Hungarian troops and temporarily turned into a royal stronghold (M. Diaconescu, Géza Érszegi, "Documenta quibus Hungariae, Valachiae et Moldaviae relationes melius illustrantur", Mediaevalia Transilvanica, II (1998), 2, pp. 283-288, at no. 1, p. 283). At that time however, the head of the family was Voicu's sonless younger brother, Radu (named also Ladislas). Radu (Ladislas) died before 1429.

${ }^{111}$ Usually, Haţeg was - historiographically - removed from this ecuation. Oltenia was accepted as part of it only in recent decades (Papacostea, "Prima unire românească', passim). In effect, in addition to the proper counties of Transylvania, a complex "appendix" (also meaning buffer-zone) stretched between Hungary and Wallachia (i.e., Muntenia east of the Olt). It consisted of the former Lands of Olt (Făgăraş, as well as Amlaş) and Severin (including Oltenia and Haţeg). The "link" between these lands was Haţeg, with the Duchy of Amlaş playing aan important, yet rather neglected part. In 1520, it was still virtually impossible to draw a border between Haţeg and northern Oltenia (see I.-A. Pop, "Din relaţiile Țării Haţegului cu Țara Românească în veacul al XV-lea şi la începutul veacului al XVI-lea", Revista de Istorie, XXXVIII (1985), 1, pp. 80-85).

112 Not only to our knowledge, but this also supposed fatherhood was never accepted by Hunyadi loyalists. Voicu was "anointed" the official father of John. The only personal story promoted by Matthias himself was that of the blood ties between him and Mehmed II. This "tale" alone was more than enough. It was first recorded in the speech of the Hungarian envoys sent to the Reichstag of Nürnberg (BStB, CLM 443, f. 176 ; December 21, 1479), following the royal anti-Ottoman victory at Câmpul Pâinii (October 13, 1479). This also led to the first - rapid - official acknowledgment of the six-year-old John as the natural son of King Matthias (MOL, DL 27714; October 21, 1479).

113 Elegantly underlined by Kubinyi (in Matthias Rex, p. 13), the peculiar relation between John Hunyadi and George Branković, the son of Vuk, Stephen Lazarević's younger brother (Momčilo Spremić, Despot Djuradj Branković i njegovo doba (Banja Luka, 19993), p. 553, nota 79), is worth closer analysis, given: (1) the conflict caused by the special (Ottoman) deal of 1444 between George 
"fashion"), ${ }^{114}$ Matthias, who often attempted to imitate Sigismund (without actually admitting it), ${ }^{115}$ had lessons to learn from his German predecessor. ${ }^{116}$ King Matthias Corvinus learnt them his own way, which usually proved to be the very hard way.

In spite of earlier promises, ${ }^{117}$ Matthias granted the estates of Ciceu and Cetatea de Baltă in central Transylvania to Stephen III only in the king's final days. ${ }^{118}$ John Hunyadi's son never returned the estates of Amlaş and Făgăraş, confiscated already by John from Wladislaw II in the early 1450s, to the various voivodes of Wallachia supported by Matthias throughout his reign. ${ }^{119}$ Matthias came close to restoring the duchies to Radu III, Vlad III's brother, and to handing-over Rodna (closer to the Moldavian border) to Stephen III, ${ }^{120}$ on the eve of the "Hungarian plot" of 1467. ${ }^{121}$ Alike the planned and delayed Habsburg-Hunyadi military intervention in support of Albanian Skanderbeg, again under heavy Ottoman attack, the project was a complete failure, largely ushering-in a new Hungarian (and regional) conspiracy against low-born Matthias. This, at least, eased a significantly more valid arrangement, on Hungarian and Wallachian soils, between King Matthias and Stephen III of Moldavia (1471). ${ }^{122}$

and John (P. Engel, "János Hunyadi and the Peace of Szeged (1444)", Acta Orientalia Academiae Scientiarum Hungaricae, XLVII (1994), 2, pp. 241-257); and (2), approximately a decade later, the "Catholic-Orthodox" engagement between Matthias and Elisabeth of Cilly, George's grand-daughter (see also Iulian Mihai Damian, Ioan de Capestrano şi cruciada târzie (Cluj-Napoca, 2011), pp. 96118).

114 BStB, CGM 5350, pp. 174, 176-177. For historiographical purposes, as well as a token of the limitations of local scholarly research, we must note that the text was copied for Nicolae Iorga as well and included in Acte şi fragmente privitoare la istoria românilor, III. [1399-1499] (Bucharest, 1899). However, the text was never used (i.e., analysed), neither by its "editor" or by other historians.

115 István Bitsky, "Höfische Representation in Ungarn während der Herrschaft von Sigismund und MatthiasCorvinus", in Das Zeitalter König Sigismunds in Ungarn und im Deutschen Reich, edited by Tilmann Schimdat, Peter Gunst (Debrecen, 2000), pp. 191-208.

${ }^{116}$ An "Eastern" (not only "Western") comparison between them could prove most relevant. For an outline: Ferenc Szakály, "Phases of Turko-Hungarian Warfare before the Battle of Mohács. 13651526", Acta Orientalia Academiae Scientiarum Hungaricae, XXXIII (1979), pp. 65-112; J. PreiserKapeller, "Sive vincitur Hungaria... Das Osmanische Reich, das Königreich Ungarn und ihre Nachbarn in der Zeit des Matthias Corvinus im Machtvergleich im Urteil griechischer Quellen", in Matthias Corvinus und seine Zeit, pp. 37-62.

${ }^{117}$ Luca-Simon, "Documentary Perspectives", p. 88 (1482).

${ }^{118}$ See Acta et epistolae relationum Transylvaniae Hungariaeque cum Moldavie et Valachia (=Fontes Rerum Transylvaniacrum, IV, VI), edited by Endre Veress, I. 1468-1540 (Budapest, 1914), no. 40, p. 44.

${ }^{119}$ Antál Lukács, Tara Făgăraşului în Evul Mediu (secolele XIII-XVI) (Bucharest, 1999), pp. 171-173.

${ }^{120}$ Biblioteca Capitular Colombiana, Sevilla, Codices, Cod. 82-4-8. Joannis Pannonii Vitesii episcopi Quinque Ecclesiarum Silvaruni Liber et Epistolae, f. 94 (January 2, 1467).

${ }^{121}$ A. Kubinyi, "Erdély a Mohács előtti évtizedekben”, in Tanulmányok Erdély történetéről, edited by István Rácz (Debrecen, 1988), pp. 65-73, at p. 67.

122 Ş. Papacostea, "Politica externă a lui Ştefan cel Mare: opţiunea polonă (1459-1472)", Studii şi Materiale de Istorie Medie, XV (2007), pp. 13-28; Pop-Simon, "The Venetian and Wallachian Roots". 